慶應義塾大学学術情報リポジトリ

Keio Associated Repository of Academic resouces

\begin{tabular}{|c|l|}
\hline Title & Goethe and French Revolution \\
\hline Sub Title & \\
\hline Author & 鈴木, 泰平(Suzuki, Taihei) \\
\hline Publisher & 三田史学会 \\
\hline Publication year & 1962 \\
\hline Jtitle & 史学 Vol.35, No.2/3 (1962. 12),p.3-3 \\
\hline JaLC DOI & \\
\hline Abstract & \\
\hline Notes & Abstract \\
\hline Genre & \\
\hline URL & https://koara.lib.keio.ac.jp/xoonips/modules/xoonips/detail.php?koara_id=AN00100104-1962120 \\
\hline
\end{tabular}

慶應義塾大学学術情報リポジトリ(KOARA)に掲載されているコンテンツの著作権は、それぞれの著作者、学会または出版社/発行者に帰属し、その権利は著作権法によって 保護されています。引用にあたっては、著作権法を遵守してご利用ください。

The copyrights of content available on the KeiO Associated Repository of Academic resources (KOARA) belong to the respective authors, academic societies, or publishers/issuers, and these rights are protected by the Japanese Copyright Act. When quoting the content, please follow the Japanese copyright act. 
government of the Consuls and started drafting of the new constitution. The ideas of Sieyès, one of the members of the revolutionary group and the theorist of it, were adopted as the foundation of the constitution. However, Napoleon Bonaparte interfered with the work of the drafting committee and proceeded to revise the draft so as to make it fit to his purpose. Thus the Constitution of the Year VIII came into being on December 13th with the signatures of the committee members and was later approved by the national plebiscite according to the provision of the constitution.

The new constitution, unlike the earlier ones, does not have in the preamble any declaration of rights and consists of only 95 articles. It is briefer than any of the preceding ones, and contains, among others, provisions for the rights of citizenship, the Senate, the legislative power, the government, the courts, and the responsibilities of public functionaries etc. The executive power resides in the three Consuls, the First Consul being entitled to the right of promulgating laws, and appointment and dismissal of officials, civil and military, and remaining two Consuls being only entitled to consultative voice. The members of the legislatures, and all the public officials central and departmental, were all elected by the people formally. Thus the ideals of Sieyes who had, under the principle of the sovereignity of people, tried to prevent the dictatorship by dividing powers, crumbled before the intervention of Napoleon Bonaparte and came to be even utilized by him for his purpose.

\section{Goethe and the French Revolution}

\section{Taihei SUzUKI}

It is a very well known fact what a great influence the French Revolution had on the formation of the German State and her people.

However, it may be stated that there were practically no one who understood sufficiently the historical significance of the progress of the Revolution. During this period, it is said, that Goethe alone understood the world historical significance of the Revolution, but so far as his works are concerned, one cannot always say that he really had complete understanding. After all, for Goethe, it might be stated that, outside of pursuing the humanities, he had almost no interest in the historical events of his time. To understand and evaluate sufficiently the Revolution and its historical significance, it was necessary to wait for the emergence of the German Romanticism. 